\title{
CT-scans of capsules from the Clarno Formation (Oregon, USA) reveal an extinct Eocene theaceous taxon
}

\author{
MACKENZIE A. SMITH* and STEVEN R. MANCHESTER \\ Florida Museum of Natural History, University of Florida, Gainesville, Florida, 32611-7800, USA; \\ e-mails: mackenziesmith@uff.edu, steven@flmnh.ufl.edu
}

Received 5 June 2020; accepted for publication 13 October 2020

\begin{abstract}
The economically important but relatively small family Theaceae can be traced back to the Late Cretaceous and is found today in the Western Hemisphere and Asia. Theaceous fruits are generally loculicidal capsules and have been found as fossils throughout the Northern Hemisphere. Using reflected light and $\mu \mathrm{CT}$ scanning, we recognize Anubiscarpon andersonae MA Smith et Manchester gen. et sp. nov. from the middle Eocene Clarno Formation of north central Oregon, based on five-valved, loculicidal capsules with a central columella, persistent perianth and pedicel, preserved as impressions in lacustrine shale. Its most distinctive feature is its apically clefted valves which are not seen in any other species of the family. Anubiscarpon augments our understanding of former morphological diversity in the Theaceae.
\end{abstract}

KEYWORDS: Anubiscarpon, Ericales, micro-CT scanning, North America, fruit, morphology

\section{INTRODUCTION}

The Eocene Clarno Formation in central Oregon contains several lacustrine deposits that yield fossil plant remains. The plants represented include Alnus clarnoensis Liu et al. (Betulaceae), Cedrelospermum Saporta (Ulmaceae), Juglandaceae, Mahonia Nutt. (Berberidaceae), Plafkeria Wolfe (Malvaceae), Platanus L. (Platanaceae), Platimeliphyllum N. Maslova (Platanaceae), Macginitiea Wolfe et Wehr (Platanaceae) and Quercus L. (Fagaceae) (Myers, 1998; Liu et al., 2014). Estimates of mean annual temperature (MAT) and mean annual precipitation (MAP) for one of these localities (White Cliffs Jr.) range from 13.382 to $20.11^{\circ} \mathrm{C}$ and 1460 to $2702 \mathrm{~mm}$ (Myers, 1998). MAT was estimated using leaf margin analysis, multiple regression analysis (MRA) and the Climate Leaf Analysis Multivariate Program (CLAMP), and MAP

\footnotetext{
Corresponding author
}

was estimated using MRA and CLAMP (Myers, 1998).

Theaceae contains nine extant genera, one of which (Franklinia W.Bartram ex Marshall) is extinct in the wild (Shi et al., 2017) (Tab. 1). The modern distribution includes Asia, southeastern North America, Central America, the Caribbean and South America (Prince, 2009). The fruits of Theaeae are mostly woody capsules, although drupes occur in some genera (Prince, 1998, 2009). Known fossils in this family go back to the Turonian stage of the Late Cretaceous (Knobloch and Mai, 1986; Martínez-Millán et al., 2009). So far, no members from Theaceae have been confirmed from the Clarno Formation. Cleyera Thunb. from the Clarno Nut Beds was previously placed in this family (Manchester, 1994), but that genus was subsequently transferred to the Pentaphylacaceae (Tsou et al., 2016).

Here we recognize a new genus and species of fossil capsular fruits of Theaceae found in 


\begin{tabular}{|c|c|c|c|c|c|c|c|c|c|c|c|}
\hline 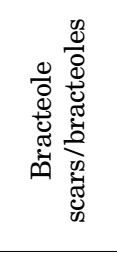 & $\begin{array}{l}10 \\
0 \\
\infty\end{array}$ & $\infty$ & N & 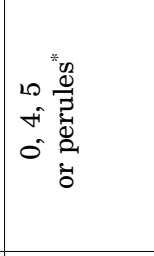 & N & $\begin{array}{c}+1 \\
0 \\
0 \\
0 \\
0 \\
0 \\
0\end{array}$ & 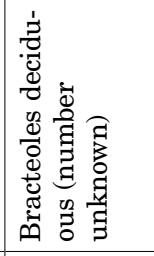 & 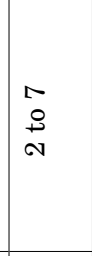 & 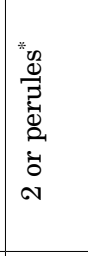 & $\infty$ & $\begin{array}{l}N \\
\stackrel{\rho}{S} \\
-1\end{array}$ \\
\hline 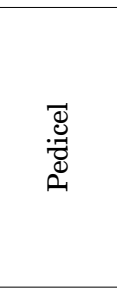 & 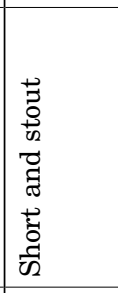 & 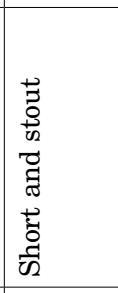 & 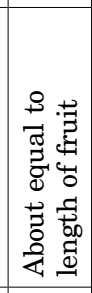 & 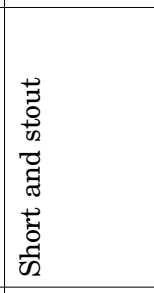 & 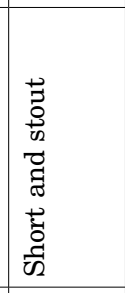 & 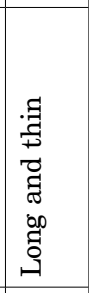 & 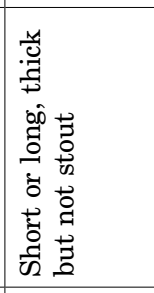 & 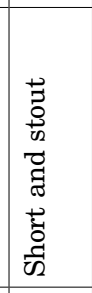 & 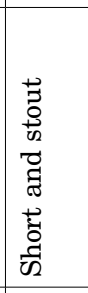 & 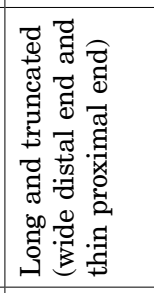 & 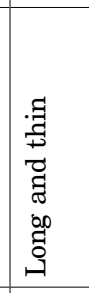 \\
\hline 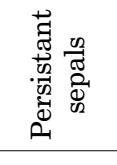 & 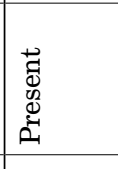 & 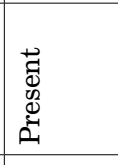 & 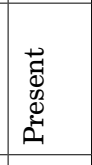 & 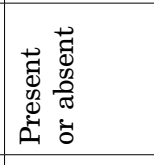 & 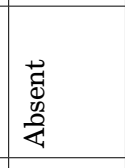 & 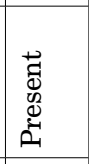 & 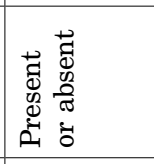 & 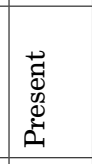 & 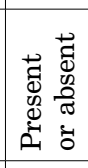 & 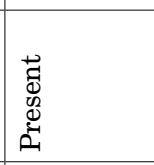 & 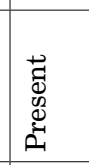 \\
\hline 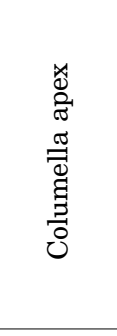 & 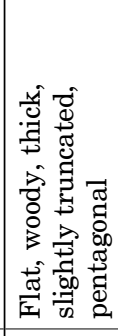 & 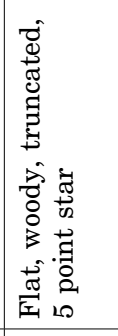 & 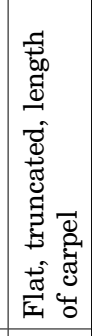 & 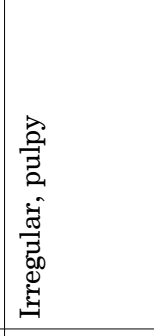 & 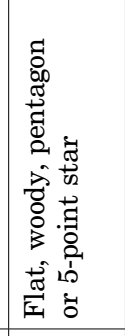 & 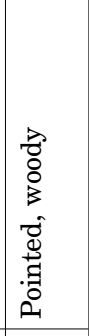 & 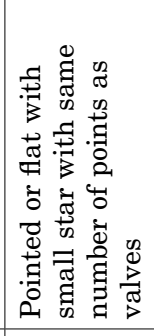 & 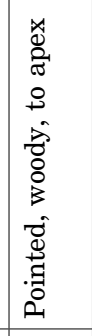 & 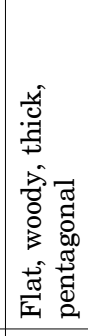 & 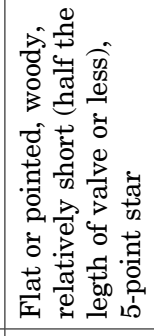 & 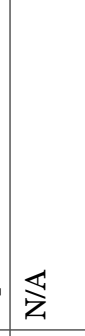 \\
\hline $\begin{array}{l}\stackrel{0}{7} \\
\stackrel{0}{\Xi} \\
\frac{0}{0} \\
0\end{array}$ & 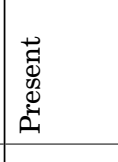 & 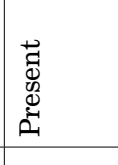 & 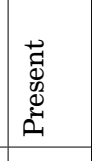 & 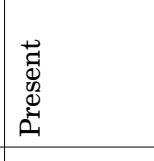 & 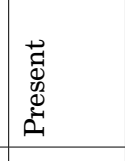 & 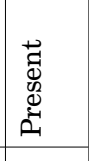 & 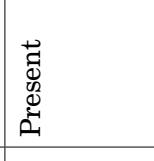 & 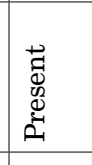 & 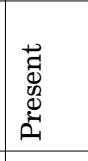 & 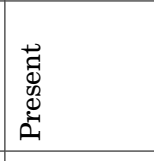 & $\begin{array}{l}\overrightarrow{0} \\
\text { प्र } \\
00 \\
\frac{0}{4}\end{array}$ \\
\hline 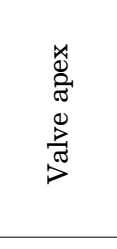 & 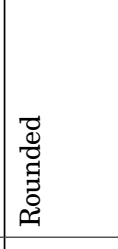 & 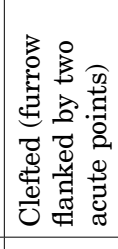 & . & 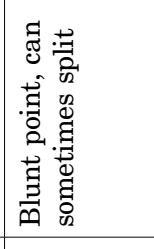 & 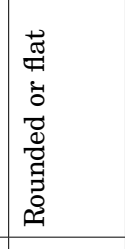 & 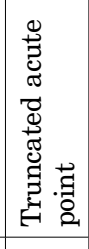 & 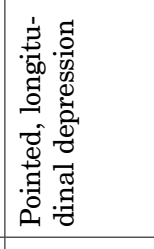 & 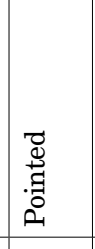 & 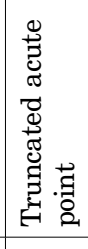 & 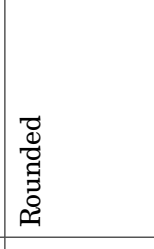 & 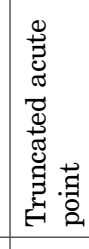 \\
\hline 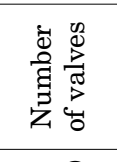 & $\begin{array}{l}10 \\
\stackrel{8}{+} \\
\forall\end{array}$ & 10 & 10 & $\begin{array}{l}10 \\
0 \\
0 \\
0\end{array}$ & 10 & $\begin{array}{l}\infty \\
\infty \\
\infty\end{array}$ & 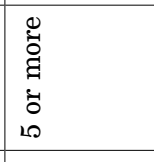 & $\begin{array}{l}\infty \\
0 \\
0\end{array}$ & $\begin{array}{l}10 \\
0 \\
0 \\
0\end{array}$ & $\begin{array}{l}\text { i } \\
\text { in }\end{array}$ & 10 \\
\hline 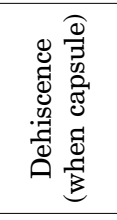 & 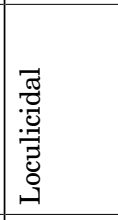 & 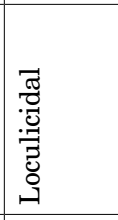 & 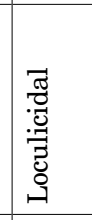 & 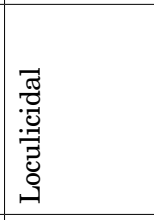 & 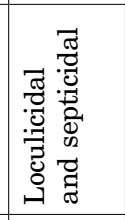 & 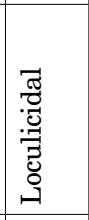 & 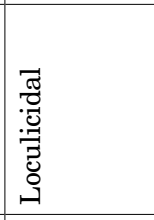 & 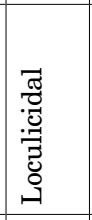 & 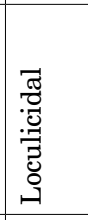 & 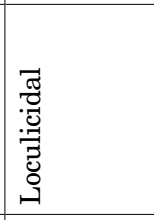 & 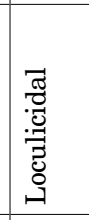 \\
\hline 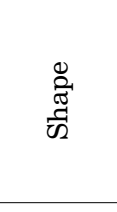 & 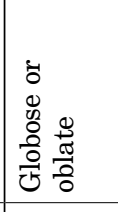 & 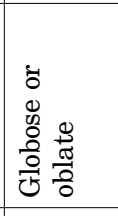 & \begin{tabular}{l}
0 \\
\multirow{2}{\pi}{} \\
0 \\
0 \\
0
\end{tabular} & 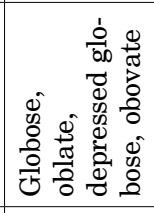 & 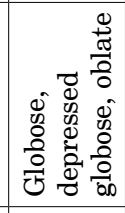 & हू. & 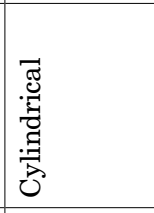 & 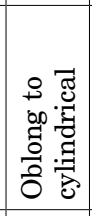 & 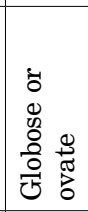 & 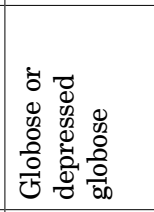 & 竞 \\
\hline 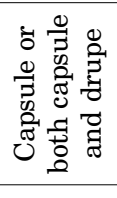 & 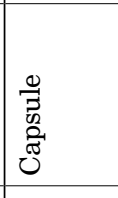 & 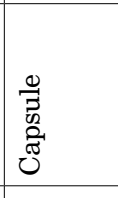 & 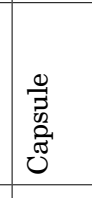 & 䓀 & 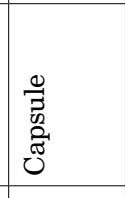 & 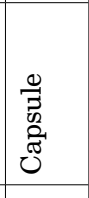 & 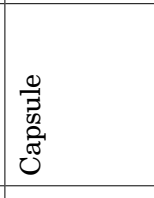 & 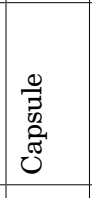 & $\begin{array}{l}\text { 芩 } \\
\text { की }\end{array}$ & 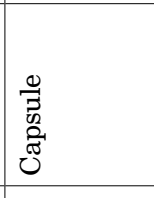 & 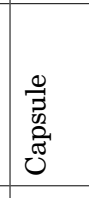 \\
\hline 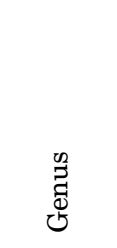 & 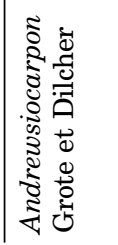 & 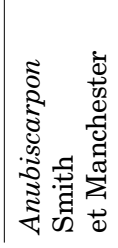 & 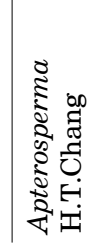 & 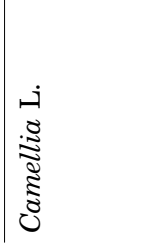 & 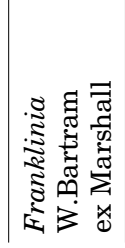 & 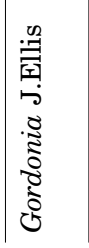 & 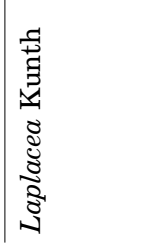 & 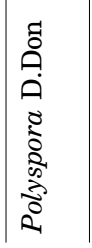 & 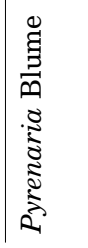 & 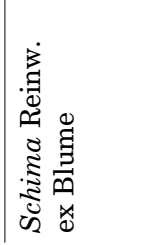 & 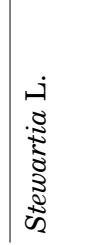 \\
\hline
\end{tabular}


lacustrine localities of the Clarno Formation in the Cherry Creek drainage of central Oregon. We document its morphology based on light microscopy and micro-CT scanning, and compare and contrast it with extant taxa. We also review the records of other fossil Theaceae in North America and Asia.

\section{MATERIALS AND METHODS}

The specimens were collected along with other plant remains from three localities in Jefferson County, central Oregon, and deposited at the Florida Museum of Natural History, University of Florida, Gainesville (UF). The sites are Red Gap (UF loc. 251; $44.73873^{\circ} \mathrm{N}, 120.4159^{\circ} \mathrm{W}$ ), White Cliffs Senior (UF loc. $\left.262 ; 44.73837^{\circ} \mathrm{N}, 120.47293^{\circ} \mathrm{W}\right)$ and White Cliffs Junior (UF loc. $263 ; 44.737267^{\circ} \mathrm{N}, 120.4735^{\circ} \mathrm{W}$ ) (Fig. 1). All three localities are estimated to be $\sim 44 \mathrm{Ma}$ (Dillhoff et al., 2009) based on ${ }^{40} \mathrm{Ar} /{ }^{39} \mathrm{Ar}$ (Manchester, 1990).

The fossils are preserved as adpressions in orangebrown lacustrine shale. They were photographed with reflected light using a Canon Rebel XSI digital camera with an EF-60-mm macro lens. In addition, micro-CT scanning was performed on a GE Phoenix V|tome |xm240 CT Scanner at the Nanoscale Research Center, University of Florida, Gainesville, Florida. For the scanning of these fossils, 2100 images were taken with x-ray specifications set to $180 \mathrm{kV}$ and $260 \mu \mathrm{A}$ for a voxel size of $47 \mu \mathrm{m}$. Avizo 9.0 Lite (FEI Visualization Science Group, Bordeaux, France) was used in processing the CT scans to obtain volume and isosurface renderings. Surface files exported as ply files in Avizo were subsequently analyzed using the lattice, $x$-ray and depth mapping rendering modules in MeshLab 2016.12 (ISTI-CNR, Italy; Cignoni et al., 2008).

\section{SYSTEMATICS}

Order: Ericales Bercht. et J.Presl

Family: Theaceae D.Don

Genus: Anubiscarpon

MA Smith et Manchester gen. nov.

Generic diagnosis. Fruitaglobose to oblate, five-valved, loculicidal capsule with a persistent columella that is over $2 / 3$ the height of the capsule, a thick pedicel and persistent hypogynous calyx. Apex of each valve prominently clefted, forming two marginal points directed distally upwards, separated by a central sinus. Pericarp composed of two woody layers.

\section{Type species. Anubiscarpon andersonae}

Etymology. The apex of each valve resembles the head of a jackal. In Egyptian mythology, Anubis is the jackal-headed god of death, an appropriate association for a fossil.

\section{Anubiscarpon andersonae}

Smith et Manchester sp. nov.

Pl. 1, figs 1-12

Holotype. UF 263-17007 (Pl. 1, fig. 1).

Other specimens. UF 251-46893, UF 25146893', UF 262-17680, UF 262-17680', UF

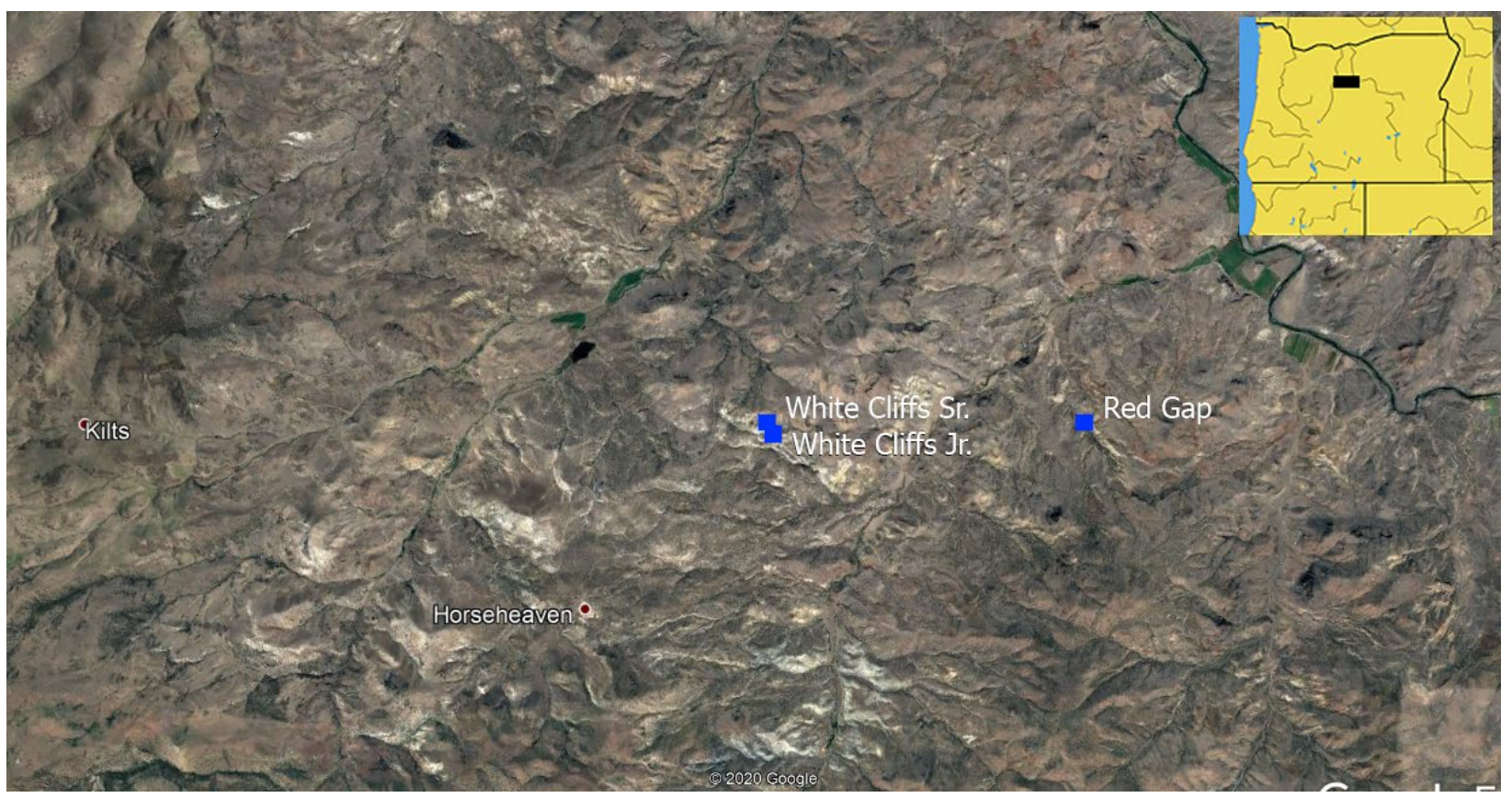

Fig. 1. UF localities 251 (Red Gap), 262 (White Cliffs Sr.) and 263 (White Cliffs Jr.), made from Google Earth (2020), with inset map showing location of field area within the Pacific Northwest 
263-17006, UF 263-17006', UF 263-17007', UF 263-17018 and UF 263-17027.

Specific diagnosis. Fruit a globose to oblate, five-valved, loculicidal capsule with a thick, short pedicel and a persistent calyx of five curved, rounded, connate sepals at the base. Three helically arranged bracteole scars present near base of pedicel. Pericarp composed of two woody layers. Each valve elongate with a median ventral septum. Valves prominently clefted apically, forming two marginal points directed distally upwards, separated by a central sinus directed towards the axis. Capsule containing a central columella that progressively enlarges toward the apex, terminating in a transversely expanded five-point star. Valves lack thickened sutures.

Etymology. The epithet andersonae honors Erica Anderson from the Washington YoungLife Ranch, Jefferson County, Oregon, who helped the authors obtain permission to collect and visit sites where some of the nicest specimens were found.

Repository. Florida Museum of Natural History (UF).

Type locality. White Cliffs Jr., Jefferson Co., Oregon $\left(44.737267^{\circ} \mathrm{N}, 120.4735^{\circ} \mathrm{W}\right)$.

Type stratum. Clarno Formation, middle Eocene.

Description and remarks. The capsules measure from 1.1 to $1.2 \mathrm{~cm}$ tall and 1.4 to $1.5 \mathrm{~cm}$ wide, with pedicels that are 4.5 to $5 \mathrm{~mm}$ tall and 3 to $4 \mathrm{~mm}$ thick (Pl. 1, figs 1-12). A lateral compression of UF 00263-17007 by reflected light shows the thick pedicel, persistent perianth and three of the capsule valves, the central one clearly showing the apical cleft (Pl. 1, fig. 1). Its counterpart (UF 263-17007') also shows the complete clefted valve in the center, with two incomplete valves on either side (Pl. 1, fig. 2). Fibers of the central columella can be discerned from the center of the capsule, extending outward from the base (Pl. 1, fig. 2). Perianth and pedicel are below (Pl. 1, fig. 2). A $\mu$-CT scan of the same specimen, using the slicer shader feature in MeshLab, reveals two complete clefted valves and a third partial valve on the left side of the fruit (Pl. 1, fig. 3). Two sepals can be seen below the fruit body (Pl. 1, fig. 3). The $\mu-\mathrm{CT}$ scan of UF 00251a-46893 with lattice shader in MeshLab shows four valves (Pl. 1, fig. 4). The left-most and right-most valves are partial; the two center valves are complete, with two apical points visible on the valve on the second to the left (Pl. 1, fig. 4). At least three sepals can be seen (Pl. 1, fig. 4). Two of the sepals point outward and are rounded (Pl. 1, fig. 4). The pedicel has three visible bracteole scars (Pl. 1, fig. 4). UF 263-17018 is a lateral compression showing under reflected light, a partial valve on the left and a full clefted valve in the center ( $\mathrm{Pl} .1$, fig. 5). Three rounded sepals can be seen below the capsule body (Pl. 1, fig. 5). A $\mu$-CT scan of the same specimen with MeshLab slicer shader reveals three clefted valves and a central columella with a flat, five-point star apex (Pl. 1, fig. 6). The valve in the center shows two apical points and a forward-facing furrow (Pl. 1, fig. 6). It appears that if the valves were closed there would be five apical points and a smooth, enclosed apical surface, with the central points of the valves fitting between and above the points of the columella's apical star (Pl. 1, figs 6, 8, 9). UF 262-1780 is a dorsal-ventral compression (Pl. 1, figs 7-9). Under reflected light, five-clefted valves with septa are visible (Pl. 1, fig. 7). A $\mu$-CT scan of the same specimen using the x-ray shader in MeshLab shows the five clefted valves and the central columella with a flattened, fivepoint star apex (Pl. 1, fig. 8). The same scan rendered with MeshLab depth map shading and HDR shows the same features with more contrast (Pl. 1, fig. 9). UF 263-17027 is a lateral compression that shows two septa, a central columella and four sepals with rounded apices under reflected light (Pl. 1, fig. 10). The same specimen observed with a $\mu$-CT scan using the MeshLab lattice shading option shows the locules (Pl. 1, fig. 11). The reverse side of the same scan and shader shows the rounded capsule and pedicel (Pl. 1, fig. 12). Seeds were not clearly visible.

Discussion. Although the locules appear to be empty, we can make inferences about the seeds. The central column indicates that placentation was probably axile. There is no evidence of scars along the length of the column that would indicate the attachment of many tiny seeds (Pl. 1, fig. 6). Rather, it appears that the star-shaped arms at the top of the column represent placentae, and that there were one or few seeds per locule (Pl. 1, figs 2, 6, 8-11). 

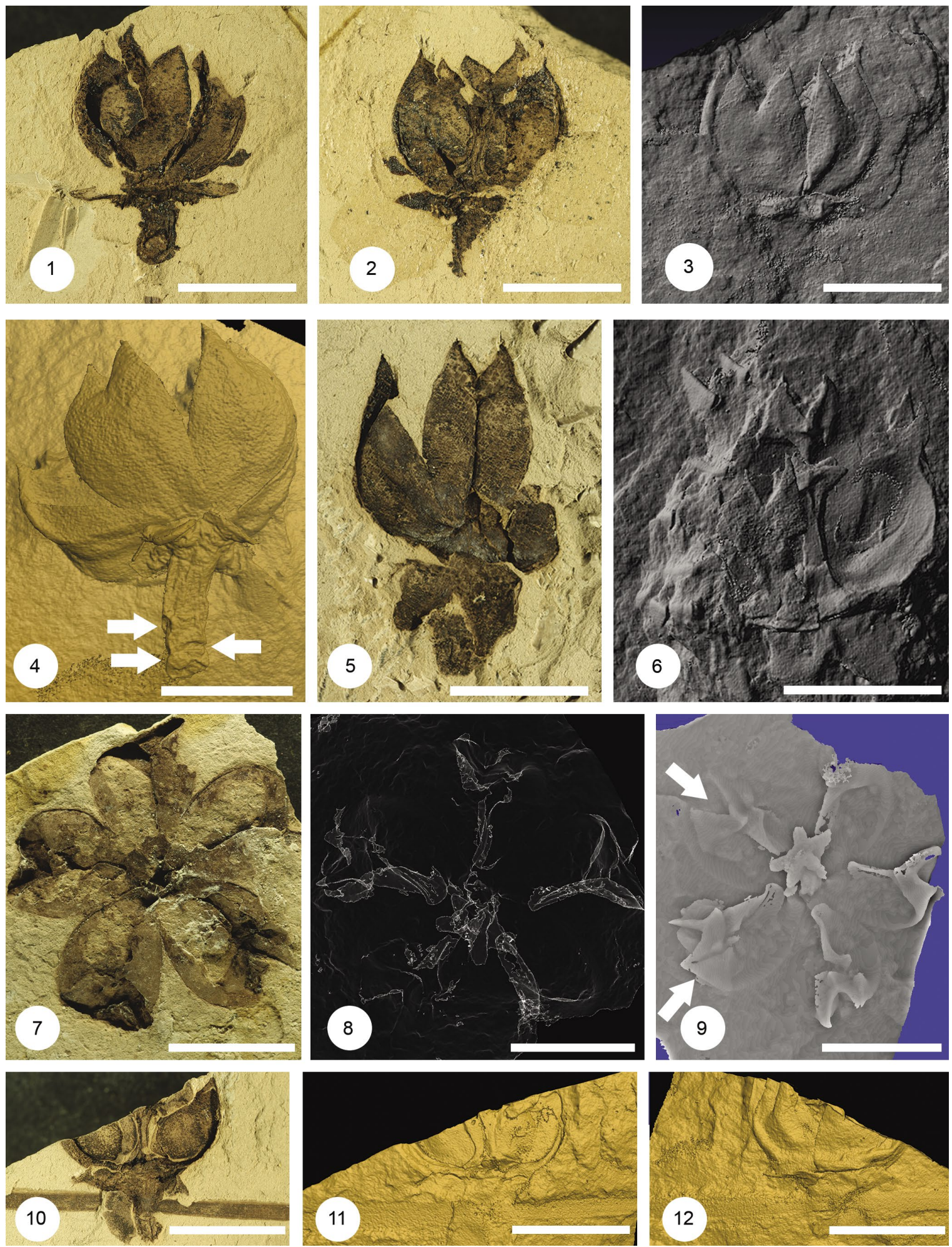

Plate 1. Anubiscarpon andersonae gen. et sp. nov. Smith et Manchester from central Oregon. 1. Holotype UF 263-17007 from White Cliffs Jr. locality, showing three valves with cleft on center valve, persistent perianth and thick pedicel; 2. UF 263-17007' from White Cliffs Jr. locality, showing three valves (with cleft on center valve), persistent columella, perianth and thick pedicel; 3. $\mu$-CT scan with MeshLab slicer shading of UF 263-17007', showing two clefted valves and edge of third with perianth; 4. UF 251a-46893 from Red Gap locality, showing four valves; two persistent, basally connate, non-imbricate sepals; thick pedicel, and three bracteole scars at white arrows; 5. UF 263-17018 from White Cliffs Jr. locality, showing three valves (two with clefts) and three sepals; 6. $\mu$-CT scan with MeshLab slicer shading of UF 263-17018, showing three clefted valves and columella tapering towards top and ending in flat, five-point star shape; 7. UF 262-1780 from White Cliffs Sr. locality, showing all five valves; 8. $\mu$-CT scan with x-ray shading of UF 262-1780, showing five loculicidal valves with clefts, septa and five-point-star-shaped apex of columella; 9. $\mu$-CT scan with depth map shading rendered in HDR of UF 262-1780, showing five loculicidal valves with clefts, septa and five-point-starshaped apex of columella (valves resembling jackal head at white arrows); 10. UF 263-17027 from White Cliffs Jr. locality, showing valves, columella and four sepals; 11. $\mu$-CT scan with MeshLab lattice shading of UF 263-17027, showing valves and columella; 12. $\mu$-CT scan with lattice shading of reverse side of UF 263-17027, showing valves, perianth and pedicel. Scale bars $=1 \mathrm{~cm}$ 
Judging from the shape of the locule, the seeds may be ovoid or pyriform (Pl. 1, figs $2,6,8-11$ ).

Extant angiosperm species with globose to oblate, five-valved, loculicidal capsules with persistent hypogynous calyx and pedicel with bracteole scars can be found most notably in Ericaceae, Malvaceae and Theaceae (Cronquist, 1981; Grote and Dilcher, 1989). Our fossil also has basally connate perianth, a character found in both the Theaceae and Malvaceae (Cronquist, 1981). Fruits with a five-pointed, flat, central columella are not found in the Malvaceae (Pfeil et al., 2002). A key feature distinguishing between the ericalean families Ericaceae and Theaceae is that Ericaceae seed coats are one cell thick (Cronquist, 1981; Grote and Dilcher, 1989). However, this criterion cannot be used because seed anatomy is not known for Anubicarpon.

Within the Ericaceae, many species bear fruit on a panicle or raceme; however, it is still possible that isolated fruits might be preserved. Agarista D.Don ex G.Don, Pieris D.Don and Leucothoë D.Don fruits are less than $1 \mathrm{~cm}$ in height and width (Judd, 1982, 1984) and Pieris has a long pedicel, persistent bracts, and sepals that extend $1 / 4$ the length of the fruit (MAS, pers. obs.). The columella of Craibiodendron W. W. Sm. is enveloped by the same woody layer that lines the locules (MAS, pers. obs.). The sepals of Zenobia D.Don appear to be longer and the valves more furrowed than in Anubiscarpon (pers. obs.). The fossil lacks the thickened sutures that are found in Lyonia Nutt. (Judd, 1982). Finally, the ericaceous fruits appear to be less robust and have thinner pedicels as compared to the fossil and to fruits of the family Theaceae.

Anubiscarpon differs from modern genera of Theaceae. Stewartia L. is more ovoid, either lacks a columella or has a short columella (only 1/2 the locule height), and has valves that taper to a fine point at the apex (Grote and Dilcher, 1989; Shi et al., 2017). Gordonia J.Ellis is also more ovoid, with tapered valves (Grote and Dilcher, 1989, 1992). In Gordonia truncata Chandler from the Eocene of England and Germany and Gordonia lamkinensis Grote et Dilcher from the Eocene of Kentucky, the columella is flat with five knobs like in Anubiscarpon (Chandler, 1926, 1961; Mai and Walther, 1985; Grote and Dilcher, 1992). Franklinia and Schima Reinw. ex Blume are globose to subglobose, like Anubiscarpon, and can have flattened, five-pointed columellae (Grote and Dilcher, 1989; Li et al., 2013; Shi et al., 2017). However, the central columella in Franklinia does not taper apically (Grote and Dilcher, 1989) and the valves open both loculicidally and septicidally. The bracteole scars on the pedicel are located closer to the fruit in Schima, differentiating it from Anubiscarpon (Shi et al., 2017). Camellia L. varies in the number of valves (3-5), number of bracteoles and if the columella is present or absent (Grote and Dilcher, 1989; Prince, 2007; Mondal, 2011). It can resemble Anubiscarpon in terms of these characters.

Among the other fossil occurrences of Theaceae, Anubiscarpon most closely resembles Andrewsiocarpon Grote et Dilcher, from the Eocene Claiborne Group of Tennessee and Kentucky, in having three to five bracteole scars (Grote and Dilcher, 1989; Wang et al., 2013). The only known species, Andrewsiocarpon henryense Grote \& Dilcher, is also of similar size, ranging from 0.9 to $2.3 \mathrm{~cm}$ wide and 0.7 to $1.9 \mathrm{~cm}$ tall (Grote and Dilcher, 1989). In addition to having clefted valves, Anubiscarpon andersonae has bracteole scars further down on its pedicel than in Andrewsiocarpon henryense. It is also possible that Anubiscarpon andersonae has more than three petiolar scars instead of the observed three from one surface plane.

The defining trait of Anubiscarpon andersonae is its apically clefted valves, which do not occur in the extant genera of Theaceae. There is some resemblance of the apex of these valves to the stigmatic protuberances of Pyrenaria Blume (Odyuo and Roy, 2017; Upadhaya et al., 2017). However, to our knowledge these protuberances only occur in the drupaceous fruits of Pyrenaria and not in species with capsular fruit (Min and Bartholomew, 2007). Further comparison with modern genera is limited by the absence of seeds in A. andersonae. Valve folding, but not clefting, occurs in Laplacea Kunth of Central and South America (Martius, 1824; UFSC Flora Digital 2020). Laplacea is also cylindrical instead of subglobose like in Apterosperma H.T.Chang from southern China and Anubiscarpon (Tab. 1). Apterosperma has two bracteole scars instead of the three found in Anubiscarpon.

Today, in temperate North America, no member of the Theaceae grows naturally outside of the southeastern United States, but the 
family was more widespread in the geological past (Grote and Dilcher, 1989). Fossil Gordonia fruits and seeds have been found in the Eocene Warman Clay Pit (Claiborne Group) of Tennessee (Wang et al., 2013), the Miocene Brandon Lignite of Vermont (Tiffney, 1981) and as leaves from the Pliocene Citronelle Formation of Alabama (Stults and Axsmith, 2015). The flower Antholithes ternstroemioides Berry from the late Eocene Wilcox flora of Tennessee is hypothesized to be a Gordonia flower (Berry, 1930). In western North America, Gordonia is reported as leaves from the Okanagan Highland early Eocene Floras (McAbee flora of British Columbia, Quilchena flora of British Columbia and Republic Flora of Washington) (Greenwood et al. 2005; Mathewes et al. 2016; Lowe et al., 2018), the late Eocene Steamboat Canyon flora of California, the late Eocene Goshen and Bilyeu/Thomas Creek floras of Oregon (Myers, 1998) and the Oligocene Chalk Bluffs Flora of California (MacGinitie, 1941). We also note Gordonia fruit from the early Oligocene Lyons flora (Meyer, 1973) of Oregon (MAS pers. obs. Phil Knutson coll.). Camellia multiforma (Potbury) Wolfe leaves have been found in the Oligocene of King County, Washington (Wolfe, 1968). Although leaf fossils have commonly been identified to extant genera, the details preserved in fossil fruits such as Andrewsiocarpon and Anubiscarpon indicate that extinct genera were present as well.

\section{CONCLUSION}

Anubiscarpon andersonae is a new genus and species of theaceous fruit, characterized as a five-valved, loculicidal capsule with clefts at the apex of each valve. The lack of preserved seeds presents a challenge to the task of establishing an extant relative and precludes its assignment to a particular clade within the family. The addition to the family highlights another case of extirpation of a family in a formally diverse area.

\section{ACKNOWLEDGEMENTS}

We thank Dr. Bruce Tiffney and an anonymous reviewer for their time and effort in reviewing the paper, Xiaoqing Zhang for finding comparative images of Apterosperma, Terry Lott for reviewing the formatting of the paper, and the individuals who collected the specimens: Dr. Thomas A. Dillhoff, T.J., G., Jason
Dunavant, L.P. and S.A.M. Support for the authors to revisit the original localities was provided by the Evolving Earth Foundation (AWD04001).

\section{REFERENCES}

Berry, E.W., 1930. Revision of the lower Eocene Wilcox flora of the southeastern states: With descriptions of new species, chiefly from Tennessee and Kentucky. United States Department of the Interior, Geological Survey Professional Paper 156, Washington D.C., 196.

Chandler, M.E.J., 1926. The Upper Eocene flora of Hordle, Hants. The Palaeontographical Society, London.

Chandler, M.E.J., 1961. Flora of the Lower Headon Beds of Hampshire and the Isle of Wight. Bulletin of the British Museum (Natural History) Geology 5, 93-157.

Cignoni, P., Callieri, M., Corsini, M., Dellepiane, M., Ganovelli, F., Ranzuglia, G., 2008. MeshLab: An open-source mesh processing tool. Computing 1, 129-136.

Cronquist, A., 1981. An integrated system of classification of flowering plants. Columbia University Press, New York, New York.

Dillhoff, R.M., Dilhoff, T.A., Dunn, R.E., Myers, J.A., Strömberg, C.A.E., 2009. Cenozoic paleobotany of the John Day Basin, central Oregon. The Geological Society of America, Field Guide 15, 135-164.

Greenwood, D.R., Archibald, S.B., Mathewes, R.W., Moss P.T., 2005. Fossil biotas from the Okanagan Highlands, southern British Columbia and northeastern Washington State: climates and ecosystems across an Eocene landscape. Canadian Journal of Earth Sciences 42, 167-185.

Grote, P.J., Dilcher, D.L., 1989. Investigations of Angiosperms from the Eocene of North America: A new genus of Theaceae based on fruit and seed remains. Botanical Gazette 150(2), 190-206.

Grote, P.J., Dilcher, D.L., 1992. Fruits and seeds from the tribe Gordonieae (Theaceae) from the Eocene of North America. American Journal of Botany 79(7), 744-753.

Judd, W.S., 1982. A taxonomic revision of Pieris (Ericaceae). Journal of the Arnold Arboretum 63(2), 103-144.

Judd, W.S., 1984. A taxonomic revision of the American species of Agarista (Ericaceae). Journal of the Arnold Arboretum 65(3), 255-342.

Knobloch, E., Mai, D.H., 1986. Monographie der Früchte und Samen in der Kreide von Mitteleuropa. Rozpravy Ústředního ústavu geologického 47, 1-219.

Li, Y., Awasthi, N., Yang, J., Li, C., 2013. Fruits of Schima (Theaceae) and seeds of Toddalia (Rutaceae) from the Miocene of Yunnan Province, China. Review of Palaeobotany and Palynology 193, 119-127. 
Liu, X., Manchester, S.R., Jin, J., 2014. Alnus subgenus Alnus in the Eocene of western North America based on leaves, associated catkins, pollen and fruits. American Journal of Botany 101(11), 1925-1943.

Lowe, A.J., Greenwood, D.R., West, C.K., Galloway, J.M., Sudermann, M., Reichgelt, T., 2018. Plant community ecology and climate on an upland volcanic landscape during the Early Eocene Climatic Optimum: McAbee Fossil Beds, British Columbia, Canada. Palaeogeography, Palaeoclimatology, Palaeoecology 511, 433-448.

MacGinitie, H.D., 1941. A middle Eocene flora from the central Sierra Nevada. Contributions to Paleontology, Carnegie Institution of Washington, Publication 534, Washington, D.C.

Mai, D.H., Walther, H., 1985. Die obereozänen Floren des Weisselster-Beckens und seiner Randgebiete. Abhandlungen des Staatlichen Museums für Mineralogie und Geologie zu Dresden 33, 5-260.

Manchester, S.R., 1990. Eocene to Oligocene floristic changes recorded in the Clarno and John Day Formations, Oregon, USA. In: Knobloch, E., Kvaček, Z. (eds), Symposium Proceedings, Paleofloristic and Paleoclimatic Changes in the Cretaceous and Tertiary. Geological Survey, Prague, Czechoslovakia, pp. $183-187$.

Manchester, S.R., 1994. Fruits and seeds of the middle Eocene Nut Beds Flora, Clarno Formation, Oregon. Palaeontographica Americana 58, 1-205.

Martínez-Millán, M., Crepet, W.L., Nixon, K.C., 2009. Pentapetalum trifasciculandricus gen. et sp. nov., a thealean fossil flower from the Raritan Formation, New Jersey, USA (Turonian, Late Cretaceous). American Journal of Botany 96(5), 933-949.

Martius, C.F.P.d., 1824. Nova genera et species plantarum: quas in itinere per Brasiliam MDCCCXVII jussu et auspiciis Maximiliani Josephi I., Bavariae regis augustissimi instituto.

Mathewes, R.W., Greenwood, D.R., Archibald S.B., 2016. Paleoenvironment of the Quilchena flora, British Columbia, during the Early Eocene Climatic Optimum. Canadian Journal of Earth Sciences 53, 1-17.

Meyer, H., 1973. The Oligocene Lyons flora of northwestern Oregon. The Ore Bin 35(3), 37-53.

Min, T., Bartholomew, B., 2007. Theaceae. In: Flora of China, Vol. 12. Science Press, pp. 363-444.

Mondal, T.K., 2011. Camellia. In: Kole, C. (ed.), Wild Crop Relatives: Genomic and Breeding Resources: Plantation and Ornamental Crops. Springer, Heidelberg, Germany, pp. 15-39.

Myers, J.A., 1998. Paleovegetational heterogeneity and the record of Eocene-Oligocene climate change in the interior Pacific Northwest. PhD, University of California, Santa Barbara, California.
Odyuo, N., Roy, D.K., 2017. Pyrenaria khasiana R.N. Paul var. lakhimpurense (Theaceae), a new variety from Assam, India. Taiwania 62(1), 29-32.

Pfeil, B.E., Brubaker, C.L., Craven, L.A., Crisp, M.D., 2002. Phylogeny of Hibiscus and the tribe Hibisceae (Malvaceae) using chloroplast DNA sequences of $\mathrm{ndhF}$ and the rpl16 intron. Systematic Botany 27(2), 333-351.

Prince, L.M., 1998. Systematics of the Theodieae (Theaceae) and the resolution of morphological, anatomical, and molecular data. $\mathrm{PhD}$, University of North Carolina, Chapel Hill.

Prince, L.M., 2007. A brief nomenclature review of genera and tribes in Theaceae. Aliso 24(1), 105-121.

Prince, L.M., 2009. Theaceae. In: Flora of North America Editorial Committee (eds), Flora of North America North of Mexico, Vol. 8. New York and Oxford, pp. 322-323.

Shi, X., Fu, Q., Jin, J., Quan, C., 2017. Mummified Oligocene fruits of Schima (Theaceae) and their systematic and biogeographic implications. Scientific Reports 7(4009), 1-9.

Stults, D.Z., Axsmith, B., 2015. New plant fossil records and paleoclimate analyses of the late Pliocene Citronelle Formation flora, U.S. Gulf Coast. Palaeontologia Electronica 18(3), 1-35 (47A).

Tiffney, B.H. 1981. Fruits of Gordonia and seeds of Cleyera? (Theaceae) from the Brandon Lignite of Vermont. Miscellaneous Series, Publication 160. Botanical Society of America, Bloomington, IN.

Tsou, C., Li, L., Vijayan, K., 2016. The intra-familial relationships of Pentaphylacaceae s.l. as revealed by DNA sequence analysis. Biochemical Genetics $54,270-282$.

UFSC FLORA DIGITAL. 2020. Fruticosa laplacea. Available from https://floradigital.ufsc.br/open sp.php?img=5832. Accessed July 2020.

Upadhaya, K., Mir, A.H., Roy, D.K., Odyuo, N., 2017. A new species of Pyrenaria (Theaceae-Theoideae) from Northeast India. Telopea: Journal of Plant Sciences 20, 35-40.

Wang, H., Blanchard, J., Dilcher, D., 2013. Fruits, seeds, and flowers from the Warman clay pit (middle Eocene Claiborne Group), western Tennessee, USA. Palaeontologia Electronica 16(3), 1-73 (21A).

Wang, Y., He, H. Min, T.L., Zhou, L.H., Fritsch, P.W., 2006. The phylogenetic position of Apterosperma (Theaceae) based on morphological and karyotype characters. Plant Systematics and Evolution 260, $39-52$.

Wolfe, J.A., 1968. Paleogene biostratigraphy of nonmarine rocks in King County, Washington. United States Geological Survey Professional Paper 571, 1-33. 